\title{
Pengaruh Corporate Governance dan Corporate Social Responsibility terhadap Kualitas Laba dan Nilai Perusahaan
}

\author{
Hennyta Hutapea ${ }^{\mathrm{a}, *}$ \\ a'Manajemen Bisnis, Politeknik Negeri Batam, henny_mercy@yahoo.com, Indonesia
}

\begin{abstract}
This study examine the effect of corporate governance (CG) and corporate social responsibility (CSR) disclosure of earnings quality and firm value. Corporate governance with board diversity is measured from the aspect of age and background study of board members. CSR disclosure in the company's annual report is measured by the score of Global Reporting Initiative (GRI). This study measures the company's earnings quality with discretionary accruals (DA), and the firm value with tobin's q ratio. This study use a sample of 160 non-financial companies listed on the Indonesia Stock Exchange (BEI) for 2010-2013, so the total observations in this study are 640 samples. The result of this study provide empirical evidence that age and background study of board members don't affect the quality of earnings and firm value, but the CSR activities affect the firm value.
\end{abstract}

Keywords: board diversity, csr, earnings quality, firm value

\section{Pendahuluan}

Perusahaan yang dijalankan oleh manajemen dalam aktivitas operasionalnya memiliki tujuan untuk memperoleh laba yang dapat meningkatkan nilai perusahaan. Manajemen sebagai pihak yang menjalankan aktivitas operasional perusahaan dikehendaki oleh pemilik perusahaan/pemegang saham untuk dapat menjalankan perusahaan dengan baik, sehingga dapat mencapai tujuan dan meningkatkan keuntungan pemegang saham. Namun, dalam praktiknya manajemen ingin mencari keuntungan sendiri dengan tidak menyajikan laporan laba yang berkualitas dan melakukan praktik earnings management. Konflik yang terjadi antara manajemen perusahaan dengan pemegang saham disebut konflik agensi/agency conflict (Jensen \& Meckling, 1976). Konflik keagenan tersebut dapat dikendalikan dengan good corporate governance (GCG) yang dapat menghindarkan praktik earnings management pada laporan keuangan yang disajikan oleh pihak manajemen (Siallagan \& Machfoedz, 2006). Kusumastuti et.al. (2007) menyatakan bahwa salah satu isu yang berkaitan dengan corporate governance (CG) adalah keberagaman dari anggota dewan direksi (board diversity). Board diversity anggota dewan direksi diukur dengan usia (age) direksi 40-50 tahun, karena pada usia tersebut seseorang dianggap telah memasuki usia yang stabil dalam karir dan pengalaman, sehingga diharapkan dapat meningkatkan nilai perusahaan. Latar belakang pendidikan (background study) ilmu manajemen, bisnis, dan ekonomi juga menjadi salah satu alat ukur board diversity dalam penelitian ini, karena background study ilmu tersebut berkaitan erat dengan praktik manajemen perusahaan.

Menurut Jo \& Harjoto (2011), salah satu trend yang dapat meningkatkan nilai perusahaan dan penting untuk diterapkan dan diungkapkan perusahaan adalah aktivitas corporate social responsibility (CSR). Aktivitas CSR telah mendapat perhatian yang baik dari pemerintah dengan adanya UU No. 40 tahun 2007 tentang Perseroan Terbatas BAB IV Pasal 66 ayat $2 b$ dan BAB V Pasal 74, yang menjadikan CSR sebagai salah satu aktivitas wajib untuk dilaksanakan oleh perusahaan. Penelitian Jo \& Harjoto (2011) yang

\footnotetext{
*Corresponding author. E-mail: henny_mercy@yahoo.com
} 
menyatakan bahwa CSR dapat meningkatkan nilai perusahaan didukung oleh Rustiarini (2010), dan Gregory et.al. (2014). Penelitian dengan hasil positif tersebut menyatakan bahwa manajemen perusahaan menyadari arti penting CSR sebagai investasi sosial jangka panjang, dan tanggung jawab perusahaan tidak hanya untuk pemegang saham saja, tetapi juga pihakpihak lain yang berkepentingan (stakeholders). Hasil penelitian yang berbeda ditemukan oleh Sixpria \& Suhartati (2013), dan Nurlela \& Islahuddin (2008) yang menyatakan bahwa aktivitas CSR tidak berpengaruh terhadap nilai perusahaan.

Rumusan masalah di dalam penelitian empiris ini adalah apakah age anggota dewan direksi mempengaruhi kualitas laba dan nilai perusahaan, apakah background study anggota dewan direksi mempengaruhi kualitas laba dan nilai perusahaan, dan apakah aktivitas CSR mempengaruhi nilai perusahaan. Tujuan penelitian ini adalah untuk mengetahui pengaruh board diversity usia (age) dan dan latar belakang pendidikan (background study) anggota dewan terhadap kualitas laba dan nilai perusahan, serta pengaruh aktivitas CSR terhadap nilai perusahaan.

\section{Kajian Literatur}

Landasan teori digunakan sebagai acuan untuk menetapkan analisis dan argumentasi atas penelitian yang dilakukan. Landasan teori yang digunakan pada penelitian ini terdiri dari teori agensi, teori kepemilikan, teori legitimasi, dan efficient market hypothesis. Teori agensi yang pertama kali dikembangkan oleh Jensen \& Meckling (1976) menyatakan bahwa biaya agensi timbul dari ketidakseimbangan dan pemisahan kepemilikan antar kepentingan pemilik/pemegang saham dan pihak manajemen perusahaan. Konflik keagenan membutuhkan pengawasan untuk memastikan pengelolaan yang dilakukan oleh manajemen dilakukan dengan penuh kepatuhan pada peraturan yang berlaku.

Teori kepemilikan terdiri dari shareholder theory (Friedman, 1970) dan stakeholder theory (Freeman, 1984). Pada teori kepemilikan ini, perusahaan harus bertanggung jawab kepada para pemilik perusahaan baik itu pemegang saham, maupun kelompok pemangku kepentingan yang lebih luas selain pemegang saham. Teori legitimasi didasarkan pada pengertian kontrak sosial yang diimplikasikan antara institusi sosial dan masyarakat. Teori ini pertama kali dikembangkan oleh Suchman (1995) yang menyatakan bahwa tindakan suatu entitas/perusahaan diharapkan dapat sesuai dengan sistem sosial yang dibangun dari norma, nilai dan keyakinan. Efficient Market Hypothesis yang dijelaskan oleh Fama (1970) menyatakan bahwa pasar dikatakan efisien bila harga yang terbentuk di pasar merupakan cerminan dari informasi keuangan yang ada.

Kusumastuti et.al. (2007) meneliti hubungan antara age anggota dewan direksi dengan nilai perusahaan, dengan asumsi semakin bertambahnya usia maka seseorang akan semakin dewasa dan dapat menghasilkan keputusan yang lebih bijaksana. Penelitian tersebut menggunakan proporsi age anggota dewan yang berusia lebih dari 40 tahun. Namun, hasil penelitian menyatakan hal berbeda, bahwa age tidak berpengaruh terhadap nilai perusahaan dan diduga semakin tua seseorang maka semakin banyak masalah kesehatan yang dihadapi sehingga pada akhirnya akan menyebabkan penurunan kemampuan intelektualnya. Hasil penelitian berbeda dikemukakan oleh Darmadi (2010) yang menyatakan bahwa age anggota dewan direksi memiliki pengaruh yang signifikan terhadap kinerja keuangan perusahaan. Adanya perbedaan hasil penelitian tersebut, mengenai pengaruh age terhadap nilai perusahaan, serta belum adanya bukti empiris yang menyatakan pengaruh age terhadap kualitas laba, mendorong peneliti untuk melakukan penelitian atas hubungan tersebut, sehingga hipotesis yang dihasilkan adalah sebagai berikut.

H1: Age anggota dewan direksi mempengaruhi kualitas laba.

$\mathrm{H} 2$ : Age anggota dewan direksi mempengaruhi nilai perusahaan.

Latar belakang pendidikan (background study) dapat mempengaruhi kompetensi seseorang. Kusumastuti et.al. (2007) menyatakan bahwa tidak ada pengaruh latar belakang pendidikan manajemen, bisnis, dan ekonomi anggota dewan direksi terhadap nilai perusahaan yang diukur dengan rasio tobin's $q$. Belum adanya penelitian empiris mengenai hubungan background study terhadap kualitas laba, juga mendorong peneliti untuk melakukan penelitian empiris terhadap pengaruh hubungan tersebut.

H3: Background study anggota dewan direksi mempengaruhi kualitas laba.

H4: Background study anggota dewan direksi mempengaruhi nilai perusahaan.

Perusahaan yang memiliki kinerja lingkungan dan sosial yang baik dan memperhatikan kepentingan 
masyarakat akan direspon positif oleh investor melalui peningkatan jumlah investasi yang berdampak pada meningkatnya harga saham. Beberapa studi dan penelitian telah dilakukan terkait hubungan antara kegiatan CSR dengan nilai perusahaan maupun kinerja perusahaan, namun hasil studi empiris masih menunjukkan perbedaan. Penelitian yang menyatakan terdapat pengaruh yang positif antara aktivitas CSR terhadap nilai perusahaan dilakukan oleh Jo \& Harjoto (2011), Gregory et.al. (2014), dan Rustiarini (2010). Jo \& Harjoto (2011) menemukan bahwa pilihan perusahaan untuk menerapkan CSR pada perusahaan memiliki pengaruh yang positif terhadap nilai perusahaan yang diukur dengan tobin's $q$. Hasil penelitian tersebut menyatakan bahwa aktivitas CSR dalam nilai perusahaan meningkatkan kemakmuran bagi pemegang saham, masyarakat, dan peraturan pemerintah.

Penelitian yang menemukan pengaruh negatif atau berpengaruh tidak signifikan dikemukakan oleh Mulyadi \& Anwar (2012), dan Sixpria \& Suhartati (2013). Penelitian Mulyadi \& Anwar (2012) menggunakan model regresi berganda dan GRI checklist sebagai alat ukur aktivitas CSR. Hasil penelitian tersebut menyatakan bahwa tidak ada hubungan yang signifikan antara CSR dan nilai perusahaan yang diukur dengan tobin's $q$. Berdasarkan hasil penelitian terdahulu yang menghasilkan kesimpulan yang tidak konsisten, hipotesis yang terbentuk dalam penelitian ini adalah: H5: Aktivitas corporate social responsibility (CSR) mempengaruhi nilai perusahaan.

\section{Metode Penelitian}

Variabel independen pada penelitian ini adalah board diversity yang diukur dengan age (AGE) dan background study (BSTUDY) anggota dewan direksi, serta aktivitas CSR. Variabel dependen terdiri dari kualitas laba yang diukur dengan discretionary accruals (DA) dan nilai perusahaan yang diukur dengan tobin's $q$ (TOBINQ). Penelitian ini memiliki beberapa variabel kontrol yaitu tingkat leverage (LEV) perusahaan, sales growth (SGROWTH), dan firm size (FSIZE).

Model regresi $\mathrm{H} 1$ yaitu pengaruh age anggota dewan direksi terhadap kualitas laba yang diukur dengan discretionary accruals (DA) adalah: DA $=\beta$ $+\beta 1 . \mathrm{AGE}+\beta 2 . \mathrm{LEV}+\beta 3$.SGROWTH $+\beta 4$.FSIZE $+\varepsilon$. Model regresi H2 yaitu pengaruh age terhadap nilai perusahaan yang diukur dengan tobin's $q$ adalah: TOBINQ $=\beta+\beta 1 . \mathrm{AGE}+\beta 2 . \mathrm{LEV}+$ $\beta 3$.SGROWTH $+\beta 4$.FSIZE $+\varepsilon$. Model regresi H3 yaitu pengaruh background study terhadap kualitas laba (discretionary accruals) adalah: $\mathrm{DA}=\beta+$ $\beta 1$. BSTUDY $+\beta 2$. LEV $+\beta 3$. SGROWTH + $\beta 4 . F S I Z E+\varepsilon$. Model regresi $\mathrm{H} 4$ yaitu pengaruh background study terhadap nilai perusahaan (tobin's $q$ ) adalah: TOBINQ $=\beta+\beta 1$.BSTUDY $+\beta 2 . \mathrm{LEV}+$ $\beta 3$.SGROWTH $+\beta 4$.FSIZE $+\varepsilon$. Model regresi H5 yaitu pengaruh aktivitas CSR terhadap nilai perusahaan adalah: TOBINQ $=\beta+\beta 1$.CSR + $\beta 2 . \mathrm{LEV}+\beta 3$.SGROWTH $+\beta 4$.FSIZE $+\varepsilon$.

Definisi operasional variabel dependen yaitu kualitas laba yang diukur dengan discretionary accruals, dihitung dengan beberapa langkah berikut (Dechow et.al., 1995):

1. Menghitung total akrual : $T A_{i t}=E A T_{i t}-C F O_{i t}$ Di mana:

$E A T_{i t}$ : Earning after tax perusahan i pada tahun $\mathrm{t}$

$\mathrm{CFO}_{\text {it }}$ : Cash Flow from Operation perusahaan I pada tahun $\mathrm{t}$

2. Menghitung nilai accruals dengan persamaan regresi OLS:

$T A_{i t}=\alpha_{1}\left(1 / A_{i t-1}\right)+\alpha_{2}\left[\Delta R E V_{i t}\right]+\alpha_{3}\left[P P E_{i t}\right]$

$+\varepsilon_{i t}$

Di mana:

$T A_{i t}$ : Total akrual perusahaan i pada tahun $\mathrm{t}$ dibagi dengan total aset perusahaan i pada tahun $\mathrm{t}-1$.

$\triangle \mathrm{REV}_{\mathrm{it}}$ : Penjualan perusahaan $\mathrm{i}$ pada tahun $\mathrm{t}$ dikurang penjualan perusahaan i pada tahun t-1 dibagi dengan total aset perusahaan i pada tahun t1 .

$A_{i t-1}$ : Total aset perusahaan i pada tahun t-1.

PPE $_{\mathrm{it}}$ : Property, plan, dan equipment perusahaan i pada tahun t dibagi total aset perusahaan i pada tahun t-1

3. Menghitung non discretionary accruals:

$N D A_{i t}=\alpha_{1}\left(1 / A_{i t-1}\right)+\alpha_{2}\left[\Delta R E V_{i t}-\right.$

$\left.\triangle R E C_{i t}\right]+\alpha_{3}\left[P P E_{i t}\right]+\varepsilon_{i t}$

Di mana:

$N D A_{i t}:$ Non discretionary accruals

$\triangle R E C_{i t}$ : Piutang bersih perusahaan i pada tahun $\mathrm{t}$ dikurang piutang bersih perusahaan i pada tahun $\mathrm{t}-1$, dibagi total aset perusahaan i pada tahun $\mathrm{t}-1$

4. Menghitung discretionary accruals:

$D A_{i t}=\left(T A_{i t} / A_{i t-1}\right)-N D A_{i t}$

Di mana: 
$D A_{i t}$ : Discretionary accruals perusahaan i pada tahun $\mathrm{t}$

Variabel dependen lainnya pada penelitian ini adalah nilai perusahaan dengan proksi tobin's $q$. Tobin's $q$ dihitung dengan rumus:

$T O B I N Q_{i t}=\left(M V E_{i t}+D E B T_{i t}\right) / T A_{i t}$

Di mana:

$M V E_{i t}$ : Closing Price x $q$ shares (closing price yang digunakan adalah harga penutupan saham 3 bulan setelah laporan keuangan dikeluarkan atau per tanggal 31 Maret) dari perusahaan i pada tahun $\mathrm{t}$

$D E B T_{i t}$ : Total hutang perusahaan i pada tahun $\mathrm{t}$

$T A_{i t}$ : Total aktiva perusahaan i pada tahun $\mathrm{t}$

Variabel independen pada penelitian ini adalah age yaitu proporsi anggota dewan direksi yang berusia 40 sampai 50 tahun pada setiap tahun observasi (dalam persentase), background study yaitu proporsi anggota dewan direksi yang memiliki latar belakang pendidikan manajemen, bisnis, ekonomi (dalam persentase), dan variabel CSR yang diukur dengan checklist Global Reporting Initiative (GRI). Penghitungan indeks pengungkapan CSR seperti yang diungkapkan oleh Haniffa \& Cooke (2005) adalah:

$\mathrm{CSR}=$ Jumlah butir pengungkapan "Ya"/Jumlah item checklist GRI (79 item)

Variabel kontrol yang digunakan pada penelitian ini adalah leverage (LEV), sales growth (SGROWTH), dan firm size (FSIZE). Leverage dihitung dengan total utang perusahaan $\mathrm{i}$ pada tahun $\mathrm{t}$ dibagi total aset perusahaan i pada tahun t. Sales growth dihitung dengan rumus: (penjualan tahun ini-penjualan tahun sebelumnya) dibagi penjualan tahun sebelumnya. Firm size (FSIZE) diukur dengan logaritma natural total aset perusahaan.

Teknik penetapan jumlah sampel dalam penelitian ini adalah dengan purposive sampling menggunakan metode judgment sampling. Perusahaan yang dijadikan sampel harus memenuhi kriteria berikut: (1) perusahaan non-finansial terdaftar di BEI yang aktif melaporkan annual report dan financial statement periode yang berakhir pada 31 Desember untuk tahun 2010-2013, (2) tidak melakukan corporate action pada tahun 2010 hingga 2013, (3) апnиal report dan financial statement disajikan dalam mata uang rupiah, (4) menyediakan informasi profil direksi dan mengungkapkan aktivitas CSR dalam annual report perusahaan. Berdasarkan kriteria penetapan jumlah sampel tersebut, diperoleh total 160 perusahaan per tahun dengan periode observasi 4 tahun, sehingga total sampel pada penelitian ini adalah 640 sampel. Jumlah perusahaan yang menjadi sampel pada penelitian ini disajikan pada Tabel 1.

Tabel 1

Jumlah Perusahaan Sampel

\begin{tabular}{lr}
\hline \multicolumn{1}{c}{ Kriteria } & Jumlah \\
\hline $\begin{array}{l}\text { Perusahaan yang terdaftar di Bursa Efek Indonesia } \\
\text { Dikurangi: Perusahaan yang bergerak dalam industri }\end{array}$ & 507 \\
keuangan & 88 \\
$\begin{array}{l}\text { Dikurangi: Perusahaan yang melakukan IPO di atas } \\
\text { Januari 2010 }\end{array}$ & 102 \\
$\begin{array}{l}\text { Dikurangi: Perusahaan yang relisting/delisting di BEI } \\
\text { tahun 2010-2013 }\end{array}$ & 3 \\
$\begin{array}{l}\text { Dikurangi: Perusahaan yang annual report dan } \\
\text { financial statement tidak lengkap }\end{array}$ & 76 \\
$\begin{array}{l}\text { Dikurangi: Perusahaan yang laporan keuangannya } \\
\text { tidak berakhir pada 31 Desember }\end{array}$ & 1 \\
$\begin{array}{l}\text { Dikurangi: Perusahaan yang menggunakan mata } \\
\text { uang selain rupiah }\end{array}$ & 42 \\
$\begin{array}{l}\text { Dikurangi: Perusahaan yang laporan tahunannya } \\
\text { tidak memiliki informasi profil direksi }\end{array}$ & 3 \\
$\begin{array}{l}\text { Dikurangi: Perusahaan yang tidak mengungkapkan } \\
\text { CSR dalam annual report }\end{array}$ & \\
Total perusahaan yang digunakan sebagai sampel \\
penelitian per tahun \\
Total observasi penelitian tahun 2010-2013
\end{tabular}

\section{Pembahasan}

Penelitian ini terdiri dari beberapa pengujian, diantaranya: uji statistik deskriptif, uji asumsi klasik, uji koefisien determinasi, uji $\mathrm{F}$ statistik dan uji $t$ statistic. Hasil uji statistik deskriptif dapat dilihat pada Tabel 2.

Berdasarkan hasil uji statistik deskriptif diperoleh nilai rata-rata variabel age adalah 0,44 dengan ratarata jumlah anggota dewan direksi adalah 5 orang. Hal tersebut berarti rata-rata perusahaan non-finansial yang menjadi sampel hanya memiliki 2 direksi yang berusia 40 hingga 50 tahun. Terdapat beberapa perusahaan yang tidak memiliki anggota dewan direksi yang berusia 40-50 tahun, karena dapat dilihat dari nilai minimal 0,00 , namun beberapa perusahaan memiliki seluruh anggota dewan direksi yang berusia 40-50 tahun karena nilai maksimal variabel ini adalah 1,00 atau $100 \%$.

Nilai mean $=0,58$ untuk variabel BSTUDY seperti pada Tabel 3.2 di atas menyatakan bahwa lebih dari $50 \%$ anggota dewan direksi perusahaan memiliki latar belakang pendidikan ilmu manajemen, bisnis, dan ekonomi. Nilai minimal BSTUDY yaitu 0,00 menunjukkan bahwa beberapa perusahaan juga tidak memiliki dewan direksi yang berlatar belakang 
manajemen, bisnis, maupun ekonomi, tetapi sebagian perusahaan memiliki seluruh anggota dewan direksi yang memiliki latar belakang pendidikan manajemen, bisnis, dan ekonomi yang dapat dilihat dari nilai maksimal BSTUDY adalah 1,00.

Tabel 2

Statistik Deskriptif Variabel Penelitian

\begin{tabular}{lccccr}
\hline & N & Min & Max & Mean & Std. Dev. \\
\hline AGE & 640 & 0,00 & 1,00 & 0,44 & 0,26 \\
BSTUDY & 640 & 0,00 & 1,00 & 0,58 & 0,22 \\
CSR & 640 & 0,01 & 0,69 & 0,18 & 0,16 \\
LEV & 640 & 0,01 & 1,72 & 0,48 & 0,28 \\
SGROWTH & 640 & $-1,00$ & 5,03 & 0,21 & 0,50 \\
FSIZE & 640 & 22,93 & 33,00 & 28,13 & 1,73 \\
DA & 640 & $-1,89$ & 1,93 & 0,04 & 0,19 \\
TOBINQ & 640 & 0,24 & 9,13 & 1,83 & 1,68 \\
JUMLAH & & & & & \\
BOARD & 640 & 2 & 11 & 5 & 1,88 \\
Valid N & 640 & & & & \\
\hline
\end{tabular}

Tabel ini merupakan hasil uji statistik deskriptif. Variabel dependen meliputi discretionary accruals (DA) dan TOBINQ, variabel independen adalah AGE, BSTUDY, CSR, LEV, SGROWTH, dan FSIZE. DA merupakan proksi kualitas laba yang dihitung dengan rumus modifikasi Jones (modified Jones'), TOBINQ $=($ MVE + DEBT $) /$ Total Aset, AGE=proporsi usia dewan direksi 40 sampai 50 tahun, BSTUDY=proporsi background study manajemen, bisnis, ekonomi anggota dewan direksi, CSR=pengungkapan CSR memakai dummy variabel 1 jika item diungkapkan dan 0 jika tidak, LEV=Total Hutang/Total Aset, SGROWTH=(penjualan tahun ini-penjualan tahun sebelumnya)/penjualan tahun sebelumnya, FSIZE=logaritma natural total aset.

Nilai rata-rata variabel $\mathrm{CSR}$ adalah 0,18 , nilai minimal variabel adalah 0,01 dan nilai maksimal adalah 0,69. Nilai rata-rata tersebut menyatakan bahwa rata-rata perusahaan sampel hanya mengungkapkan 14 hingga 15 poin dari total 79 item pengungkapan CSR. Hasil nilai minimal dan maksimal yang berbeda menyatakan bahwa perusahan-perusahaan non-finansial kurang memperhatikan kegunaan pelaksanaan aktivitas CSR pada penilaian masyarakat sosial terhadap perusahaan.

Variabel kontrol LEV memiliki nilai rata-rata 0,48 , nilai minimal 0,01 , dan nilai maksimal 1,72 . Nilai rata-rata leverage yang hampir $50 \%$ tersebut dapat menjadi pertimbangan pemegang saham perusahaan dalam mengambil keputusan yang berkaitan dengan keputusan risiko, karena tingkat risiko perusahaan tidak dapat mengembalikan aktiva pemegang saham di masa yang akan datang adalah $48 \%$. Variabel SGROWTH memiliki nilai rata-rata 0,21 , nilai minimal -1,00, dan nilai maksimal 5,03. Hal tersebut mengindikasikan bahwa pertumbuhan penjualan perusahaan sampel belum seluruhnya merata. Semakin tinggi angka sales growth, maka perusahaan mengalami pertumbuhan penjualan yang bagus. Variabel FSIZE memiliki nilai rata-rata 28,13 , nilai minimal variabel adalah 22,93, dan nilai maksimal variabel adalah 33,00. Jumlah total aset yang semakin meningkat dan bertambah menunjukkan bahwa semakin meningkat dan bertambah pula ukuran perusahaan yang diteliti.

Variabel dependen discretionary accruals (DA) merupakan proksi kualitas laba dengan nilai rata-rata 0,04. Nilai minimal variabel adalah $-1,89$, dan nilai maksimal adalah 1,93 . Rentang yang jauh antara nilai minimal dan maksimal tersebut menunjukkan bahwa praktik earnings management yang dilakukan oleh perusahaan sangat bervariasi. Nilai DA yang tinggi menunjukkan bahwa praktik earnings management yang dilakukan oleh manajemen perusahaan juga tinggi, sehingga kualitas laba perusahaan menurun. Variabel TOBINQ yang merupakan alat ukur nilai perusahaan memiliki nilai mean 1,83 , nilai minimal 0,24 , nilai maksimal 9,13 . Hal tersebut menyatakan bahwa rata-rata nilai perusahaan selama tahun 2010 hingga 2013 masih positif. Nilai perusahaan yang tinggi menunjukkan persepsi investor terhadap tingkat keberhasilan perusahaan yang sering dikaitkan dengan harga saham, yaitu harga saham yang tinggi akan membuat nilai perusahaan juga tinggi, dan pasar dapat merespon harga saham lebih tinggi daripada nilai buku saham perusahaan.

Setelah melakukan uji statistik deskriptif, maka selanjutnya dilakukan penelitian atas uji asumsi klasik. Penelitian ini merupakan penelitian data panel, yang menurut Nachrowi \& Usman (2006) dalam Lestari et.al. (2014), pengujian asumsi klasik untuk data panel hanya uji multikolinearitas dan masalah heteroskedastisitas, karena data panel merupakan gabungan antara data cross section dan data time series sehingga tidak mensyaratkan persamaan bebas normalitas dan autokorelasi. Uji multikolinearitas untuk mengetahui apakah terdapat korelasi yang sempurna antar variabel bebas di dalam suatu persamaan model regresi berganda dapat dilihat dari nilai variance inflation factor (VIF). Persamaan regresi yang baik adalah yang bebas masalah multikolinearitas, dilihat dari nilai $\mathrm{VIF} \leq 10$. Berdasarkan hasil penelitian pada Tabel 3 hingga Tabel 7 di bawah diperoleh nilai VIF untuk seluruh persamaan regresi $\leq 10$, sehingga persamaan regresi pada penelitian ini bebas dari masalah multikolinearitas. Uji asumsi klasik lainnya yaitu uji heteroskedastisitas diuji dengan program EViews 6.0 dengan uji white heteroskedasticity. Persamaan regresi yang baik adalah yang bebas masalah heteroskedastisitas dengan melihat nilai Prob.Chi- 
square $>0,05$. Berdasarkan hasil uji white pada kelima model penelitian, H1 memiliki nilai Prob.Chi-square = 0,7389, H2 memiliki nilai Prob.Chi-square $=$ 0,4794, H3 memiliki nilai Prob.Chi-square $=0,1676$, H4 memiliki nilai Prob.Chi-square = 0,7361, dan H5 memiliki nilai Prob.Chi-square $=0,9903$, sehingga dapat disimpulkan bahwa seluruh model regresi bebas dari masalah heteroskedastisitas.

Tabel 3

Pengaruh Age Anggota Dewan Direksi terhadap Kualitas Laba

\begin{tabular}{|c|c|c|c|c|}
\hline & $\begin{array}{l}\text { Expected } \\
\text { Sign }\end{array}$ & Coefficients & p-value & VIF \\
\hline $\mathrm{AGE}$ & \pm & 0,0178 & 0,6834 & 1,01 \\
\hline LEV & \pm & 0,0009 & 0,7135 & 1,00 \\
\hline SGROWTH & \pm & 0,0227 & 0,1452 & 1,00 \\
\hline FSIZE & \pm & 0,2054 & $* * * 0,0000$ & 1,02 \\
\hline (constant) & $\neq$ & $-5,7474$ & $* * * 0,0000$ & \\
\hline \multicolumn{3}{|l|}{ R-squared } & 0,4629 & \\
\hline \multicolumn{3}{|c|}{ Adjusted R-squared } & 0,2790 & \\
\hline \multicolumn{3}{|c|}{ F-test Sign (F-statistic) } & $* * * 0,0000$ & \\
\hline \multicolumn{3}{|c|}{$\mathrm{N}$} & 640 & \\
\hline \multicolumn{3}{|c|}{ Hasil Uji Hausman Test } & Fixed Effect & \\
\hline
\end{tabular}

Berdasarkan Tabel 3 dapat dilihat bahwa nilai Adjusted $R$-squared adalah 0,2790. Nilai Adjusted $R$ squared yang lebih besar dari 0,05 tersebut menyatakan bahwa variabel independen AGE dan variabel kontrol LEV, SGROWTH, dan FSIZE dapat menjelaskan $27,90 \%$ variasi variabel DA, dan sisanya sebesar 72,10\% dijelaskan oleh faktor-faktor lain yang tidak termasuk dalam persamaan penelitian. Uji Fstatistik H1 menghasilkan nilai $p$-value $=0,0000$ yang berarti variabel independen dan kontrol bersama-sama mempengaruhi kualitas laba yang diukur dengan discretionary accruals (DA). Hasil uji hipotesis $t$ statistic H1 dapat dilihat dari nilai $p$-value. Berdasarkan Tabel 3, variabel independen AGE secara parsial tidak berpengaruh terhadap discretionary accruals. Hasil tersebut menunjukkan bahwa usia (age) anggota dewan direksi tidak mempengaruhi nilai perusahaan, dan meskipun direksi perusahaan berada pada usia yang proporsional tidak dapat menghindarkan perusahaan dari praktik manajemen laba yang mengakibatkan kualitas laba menurun. Variabel kontrol yang berpengaruh terhadap kualitas laba adalah firm size pada level signifikansi $1 \%$, sedangkan variabel kontrol lainnya yaitu LEV dan SGROWTH tidak berpengaruh terhadap kualitas laba.

Hasil pengujian $\mathrm{H} 2$ yaitu pengaruh age terhadap nilai perusahaan yang diukur dengan tobin's $q$ menghasilkan kesimpulan bahwa age tidak mempengaruhi nilai perusahaan. Hal tersebut dapat dilihat dari nilai $p$-value variabel age yang tidak signifikan pada level 1\%, 5\%, maupun $10 \%$. Hasil penelitian $\mathrm{H} 2$ disajikan pada Tabel 4.

Tabel 4

Pengaruh Age Anggota Dewan Direksi terhadap Nilai Perusahaan (Tobin's Q)

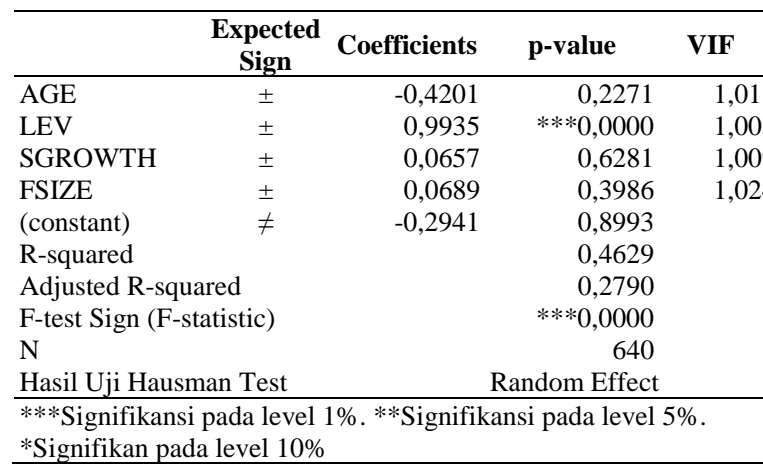

Pada Tabel 4, variabel yang berpengaruh terhadap nilai perusahaan adalah tingkat leverage yang signifikan pada level signifikansi 1\%. Pengujian pengaruh variabel independen AGE terhadap nilai perusahaan menyatakan bahwa AGE tidak mempengaruhi nilai perusahaan, sehingga dapat diambil kesimpulan bahwa meskipun perusahaan memiliki anggota dewan direksi dengan usia 40 hingga 50 tahun, kinerja dewan direksi tersebut tidak dapat meningkatkan nilai perusahaan.

Penelitian pengaruh background study (BSTUDY) anggota dewan direksi terhadap kualitas laba dilakukan dengan uji hausman test dan menghasilkan fixed effect model sebagai metode estimasi data panel yang tepat. Hasil penelitian terhadap pengaruh ini menghasilkan bahwa background study tidak mempengaruhi kualitas laba yang diukur dengan discretionary accruals. Nilai p-value variabel BSTUDY adalah 0,2950 yang berarti variabel tersebut tidak signifikan pada level signifikansi $1 \%, 5 \%$, maupun $10 \%$. Hasil tersebut menggambarkan bahwa meskipun sebuah perusahaan memiliki anggota dewan direksi dengan latar belakang pendidikan yang sesuai dengan jabatan manajemen yaitu pendidikan manajemen, bisnis, dan ekonomi, tidak dapat menjamin conflict agency yang dilaksanakan oleh manajemen tidak terjadi yang berakibat pada menurunnya kualitas laba. Berdasarkan Tabel 5, variabel kontrol yang berpengaruh terhadap kualitas laba adalah FSIZE pada level signifikansi $1 \%$. Variabel kontrol lainnya yaitu LEV dan SGROWTH tidak berpengaruh terhadap kualitas laba. 
Tabel 5

Pengaruh Background Study Anggota Dewan Direksi terhadap Kualitas Laba

\begin{tabular}{lcrrr}
\hline & $\begin{array}{c}\text { Expected } \\
\text { Sign }\end{array}$ & Coefficients & p-value & VIF \\
\hline BSTUDY & \pm & 0,0523 & 0,2950 & 1,00 \\
LEV & \pm & 0,0009 & 0,7101 & 1,00 \\
SGROWTH & \pm & 0,0226 & 0,1453 & 1,00 \\
FSIZE & \pm & 0,2048 & $* * * 0,0000$ & 1,01 \\
(constant) & $\neq$ & $-5,7540$ & $* * * 0,0000$ \\
R-squared & & 0,4640 \\
Adjusted R-squared & & 0,2805 \\
F-test Sign (F-statistic) & \multicolumn{3}{c}{ Fixed Effect } \\
N & & 6,0000 \\
Hasil Uji Hausman Test & & \\
***Signifikansi pada level 1\%. **Signifikansi pada level 5\%. \\
*Signifikan pada level 10\%
\end{tabular}

Hasil penelitian H4 mengenai pengaruh BSTUDY terhadap nilai perusahaan (TOBINQ) disajikan pada Tabel 6 .

Tabel 6

Pengaruh Background Study Anggota Dewan Direksi terhadap Nilai Perusahaan

\begin{tabular}{|c|c|c|c|c|}
\hline & $\begin{array}{c}\text { Expected } \\
\text { Sign }\end{array}$ & Coefficients & p-value & VIF \\
\hline BSTUDY & \pm & 0,4577 & 0,2552 & 1,00 \\
\hline LEV & \pm & 0,9933 & $* * * 0,0000$ & 1,00 \\
\hline SGROWTH & \pm & 0,0529 & 0,6960 & 1,00 \\
\hline FSIZE & \pm & 0,0832 & 0,3038 & 1,01 \\
\hline (constant) & $\neq$ & $-1,1422$ & 0,6192 & \\
\hline R-squared & & & 0,7716 & \\
\hline Adjusted R-s & red & & 0,7702 & \\
\hline F-test Sign (F & atistic) & & $* * * 0,0000$ & \\
\hline $\mathrm{N}$ & & & 640 & \\
\hline Hasil Uji Hau & Ian Test & & Random Effect & \\
\hline
\end{tabular}

Berdasarkan Tabel 6, variabel BSTUDY dengan nilai p-value 0,2552 tidak mempengaruhi nilai perusahaan yang diukur dengan tobin's $q$. Hal tersebut dapat terjadi karena pada sebuah perusahaan terdapat struktur organisasi dan job description yang berbedabeda, sehingga perusahaan sebaiknya mengangkat/ merekrut dewan direksi yang berkompeten dibidangnya dan memiliki background study yang sesuai dengan kebutuhan pada divisi masing-masing perusahaan, sehingga diharapkan dapat meningkatkan nilai perusahaan. Hasil penelitian ini sesuai dengan penelitian yang dilakukan oleh Hambrick et.al. (1996), Herrmann \& Datta (2005) yang menyatakan bahwa tingkat pendidikan rata-rata tim manajemen puncak terkait dengan ukuran kinerja dan bidang usaha pada perusahaan, sehingga latar belakang pendidikan manajemen, bisnis, dan ekonomi bukan menjadi tolak ukur untuk menjabat sebagai dewan direksi pada sebuah perusahaan.

Pengujian atas variabel kontrol pada model regresi ini menunjukkan bahwa variabel leverage (LEV) berpengaruh terhadap nilai perusahaan dengan level signifikansi $1 \%$. Variabel kontrol lainnya yaitu SGROWTH dan FSIZE tidak mempengaruhi nilai perusahaan.

Hasil penelitian atas $\mathrm{H} 5$ yang menguji pengaruh aktivitas corporate social responsibility (CSR) terhadap nilai perusahaan disajikan pada Tabel 7 .

Tabel 7

Pengaruh Aktivitas CSR terhadap Nilai Perusahaan

\begin{tabular}{|c|c|c|c|c|}
\hline & $\begin{array}{l}\text { Expected } \\
\text { Sign }\end{array}$ & Coefficients & p-value & VIF \\
\hline CSR & \pm & 1,4477 & $* 0,0943$ & 1,19 \\
\hline LEV & \pm & 0,9946 & $* * * 0,0000$ & 1,00 \\
\hline SGROWTH & \pm & 0,0679 & 0,6166 & 1,00 \\
\hline FSIZE & \pm & 0,0329 & 0,7011 & 1,20 \\
\hline (constant) & $\neq$ & 0,2699 & 0,9093 & \\
\hline R-squared & & & 0,7721 & \\
\hline Adjusted R-s & red & & 0,7040 & \\
\hline F-test Sign (F & atistic) & & $* * * 0,0000$ & \\
\hline $\mathrm{N}$ & & & 640 & \\
\hline \multicolumn{2}{|c|}{ Hasil Uji Hausman Test } & \multicolumn{3}{|c|}{ Random Effect } \\
\hline $\begin{array}{l}* * * \text { Signifikar } \\
* \text { Signifikan } \mathrm{p}\end{array}$ & $\begin{array}{l}\text { pada level } \\
\text { level } 10 \%\end{array}$ & \%. **Signi & kansi pada level & \\
\hline
\end{tabular}

Berdasarkan Tabel 7, variabel CSR memiliki koefisien positif dan signifikan pada level signifikansi 10\%. Hal tersebut berarti aktivitas CSR yang dilaksanakan oleh perusahaan mempengaruhi nilai perusahaan, dengan dapat meningkatkan citra perusahaan sehingga nilai perusahaan juga akan meningkat. Hasil penelitian ini menerima legitimacy theory yang dikemukakan pertama kali oleh Suchman (1995) bahwa tindakan suatu entitas perusahaan harus dibangun dari norma, nilai, dan keyakinan dengan sistem sosial dan masyarakat yang akan meningkatkan nilai perusahaan. Hasil pengujian atas variabel kontrol pada model regresi ini menyatakan bahwa variabel leverage (LEV) berpengaruh terhadap nilai perusahaan dengan level signifikansi $1 \%$ ( $p$-value 0,0000). Variabel kontrol lainnya yaitu sales growth (SGROWTH) dan firm size (FSIZE) menunjukkan hasil yang berbeda dan tidak berpengaruh terhadap nilai perusahaan.

\section{Kesimpulan}

Penelitian ini bertujuan untuk mengetahui pengaruh GCG yang diukur dengan board diversity proksi age dan background study terhadap kualitas laba dan nilai 
perusahaan, serta pengaruh aktivitas CSR terhadap nilai perusahaan. Jumlah sampel penelitian adalah 160 perusahaan dengan tahun observasi 2010-2013, sehingga total observasi penelitian adalah 640. Hasil penelitian menunjukkan bahwa usia (age) anggota dewan direksi tidak mempengaruhi kualitas laba dan nilai perusahaan. Hasil penelitian background study menunjukkan bahwa background study tidak mempengaruhi kualitas laba dan nilai perusahaan. Hasil penelitian lainnya mengenai pengaruh aktivitas CSR terhadap nilai perusahaan menyatakan bahwa CSR mempengaruhi perusahaan dengan dapat meningkatkan nilai perusahaan.

\section{References}

Darmadi, S. (2010). Board Diversity and Firm Performance: The Indonesian Evidence. Munisch Personal Repec Archive.

Dechow, P. M., Sloan, R. G., \& Sweeney, A. P. (1995). Detecting Earnings Management. The Accounting Review, 193-225.

Fama, E. F. (1970). Efficient Capital Markets: A Review of Theory and Empirical Work. Journal of Finance, 383-417.

Freeman, R. E. (1984). Stakeholder Theory of The Modern Corporation. Journal of Business Ethics.

Friedman, M. (1970). The Social Responsibility of Business is to Increase Its Profits. The New York Times Magazine.

Gregory, A., Tharyan, R., \& Whittaker, J. (2014). Corporate Social Responsibility and Firm Value: Disaggregating The Effects on Cash Flow, Risk and Growth. Journal of Business Ethics, 124:633-657.

Hambrick, D. C., Cho, T. S., \& Chen, M.-J. (1996). The Influence of Top Management Team Heterogeneity on Firm's Competitive Moves. Administrative Science Quarterly, 659.

Haniffa, R. M., \& Cooke, T. E. (2005). The Impact of Culture and Governance on Corporate Social Reporting. Journal of Accounting and Public Policy 24, 391-430.
Herrmann, P., \& Datta, D. K. (2005). Relationships Between Top Management Team Characteristics and International Diversification: an Empirical Investigation. British Journal of Management.

Jensen, M. C., \& Meckling, W. H. (1976). Theory of The Firm: Managerial Behavior, Agency Cost and Ownership Structure. Journal of Financial Economics 3 , 305-360.

Jo, H., \& Harjoto, M. A. (2011). Corporate Governance and Firm Value: The Impact of Corporate Social Responsibility. Journal of Business Ethics, 103:351-383.

Kusumastuti, S., Supatmi, \& Sastra, P. (2007). Pengaruh Board Diversity terhadap Nilai Perusahaan dalam Perspektif Corporate Governance. Jurnal Akuntansi dan Keuangan, Vol.9, 88-98.

Lestari, N., Wardhani, R., \& Anggraita, V. (2014). Pengaruh Perencanaan Pajak terhadap Nilai Perusahaan dengan Moderasi Corporate Governance. Simposium Nasional Akuntansi 17 Mataram, Lombok.

Mulyadi, M. S., \& Anwar, Y. (2012). Impact of Corporate Social Responsibility Toward Firm Value and Profitability. The Business Review, Cambridge Vol. 19, Num.2.

Nurlela, R., \& Islahuddin. (2008). Pengaruh Corporate Social Responsibility terhadap Nilai Perusahaan dengan Prosentase Kepemilikan Manajemen sebagai Variabal Moderating. Simposium Nasional Akuntansi XI Pontianak.

Rustiarini, N. W. (2010). Pengaruh Corporate Governance pada Hubungan Corporate Social Responsibility dan Nilai Perusahaan. Simposium Nasional Akuntansi XIII Purwokerto.

Siallagan, H., \& Machfoedz, M. (2006). Mekanisme Corporate Governance, Kualitas Laba dan Nilai Perusahaan. Simposium Nasional Akuntansi 9 Padang.

Sixpria, N., \& Suhartati, T. (2013). Pengaruh Pengungkapan Tanggung Jawab Sosial dan Praktik Tata Kelola Perusahaan terhadap Nilai Perusahaan. Simposium Nasional Akuntansi XVI.

Suchman, M. C. (1995). Managing Legitimacy: Strategic and Institutional Approaches. Academy of Management Journal. 